Article

\title{
Integrating Sustainability in Organisations: An Activity-Based Sustainability Model
}

\author{
Ana Rodríguez-Olalla *, ${ }^{\dagger}$ and Carmen Avilés-Palacios *, + \\ Escuela Técnica Superior de Ingeniería de Montes, Forestal y del Medio Natural, \\ Universidad Politécnica de Madrid, Camino de las Moreras, s/n, 28040 Madrid, Spain \\ * Correspondence: ana.rolalla@gmail.com (A.R.-O.); carmen.aviles@upm.es; (C.A.-P.); \\ Tel.: +34-653-462-793 (A.R.-O.); +34-696-109-900 (C.A.-P.) \\ + These authors contributed equally to this work.
}

Received: 17 April 2017; Accepted: 19 June 2017; Published: 20 June 2017

\begin{abstract}
Organisations have become interested in using integral management systems to increase their sustainable value. Although global integration models address sustainability in organisations, these models present shortcomings and limitations and do not describe how to achieve the integration of sustainability. This paper proposes an Activity-Based Sustainability (ABS) integration model that complements other models from an inside-out perspective. Its assessment follows a procedure similar to that proposed by the Activity-Based Costing (ABC) model of cost accounting. The model assigns impacts from activities in the value chain of a process to the objects of impact (products, services, clients, or markets) that must be managed in terms of sustainability. The main limitations of the ABS model are the need to identify and describe processes, to locate every activity that constitutes the value chain, and to quantify the impacts of these activities. The ABS model is presented as an alternative to link sustainable management accounting and sustainable communication, as well as sustainable management control and sustainability assessment. It connects these sustainable elements through the bilateral identification of the linkages among skills, processes, and practices. It also links these aspects with the contribution to sustainable development and the development of competitive advantages.
\end{abstract}

Keywords: integrated sustainability models; sustainability; sustainable management; organisational sustainability; sustainability integration; sustainable value chain

\section{Introduction}

Organisations must increase their value to become competitive [1]. In recent years, the analysis of value has focused on how these organisations achieve sustainability. Sustainable value is understood as involving the management and measurement of sustainability performance. This can be accomplished through the assessment and aggregation of economic, environmental, and social resources [2], and of the tangible or intangible qualities of the activities and/or processes that organisations perform to achieve a balance among economic performance, natural capital conservation, and social and human justice.

However, the process of integrating and implementing sustainability in organisations is complex for several reasons. First, there is no clear definition of sustainability in general, let alone the sustainability of organisations [3]. Second, there are various theoretical approaches that justify the inclusion of sustainability as an organisational value [4] and various methods of implementing sustainable practices at different organisational levels [5]. Thus, some research suggests that corporate social responsibility (CSR) must be the strategy to create sustainable organisations [1,6], whereas other studies argue that this must be achieved using the Triple Bottom Line $[7,8]$. Still other authors assert that organisations will be sustainable if they implement strategic change and take action with regard 
to the structural elements of organisations $[9,10]$. Finally, there are no standard models for the global integration of sustainability in organisations. What organisations need to know is precisely how they can implement sustainability in their daily operations, as well as strategies in the medium and long term [11] (in a simple manner) that use management systems that they have already implemented. Therefore, the research question in this study is as follows: given existing sustainability integration models, is there a framework to implement sustainability in a simple manner that can enhance the organisational value chain?

To answer this question, this paper focuses on the analysis of the integration models proposed by Maas et al. [12] and Morioka and de Carvalho [13]. Both of these models attempt to integrate sustainability as a way of increasing the value of organisations, but neither of them explains how to achieve this goal. To remedy this shortcoming, an Activity-Based Sustainability model (ABS) is proposed. This model not only integrates organisational sustainability using previously implemented management systems, but also offers useful information for decision making regarding the social, environmental, and economic impacts of all of these aspects, as well as the activities that organisations perform to facilitate their sustainable management. This model makes it possible to link resources, activities, and processes.

The article is structured as follows: first, the concept of sustainable organisations is defined, and the different methods, models, and tools for the integration of sustainability into organisations are described; second, the paper examines integration models of sustainability and the concept of a sustainable value chain as underlying constructs of a new sustainability integration model; And third, the basis, processes and scope of the ABS model are explained. In the subsequent section, the implications of the ABS model and its applications for the integration of other models of sustainability (such as those proposed by Maas et al. [12] and Morika and de Carvalho [13]) are discussed. Finally, contributions, expected results, and limitations of the ABS model (as well as possible lines of future research) are presented.

\section{Literature Review}

Sustainability is an ambiguous concept [14] that can be analysed from different perspectives and dimensions [15], with a focus on the subjects of biology, ecology, and economics [16].

\subsection{Sustainable Organisations}

With regard to organisations, there is no consensus regarding the definition of organisational sustainability $[3,16]$. Organisational sustainability can be considered a multidimensional phenomenon that focuses on maintaining results, generating knowledge, building capacity, establishing experiences with partners, and producing services and products based on the concepts of efficiency and effectiveness [17]. However, there is no broad consensus regarding this concept [16]. This phenomenon must achieve a balance among economic, environmental, and social dimensions [18-21]. Figge et al. [22] note that this balance must be oriented towards improving organisational performance.

Lankoski [3] describes sustainability in organisations using four constructs. The first construct equates sustainability in organisations with sustainable development, linking it to socio-economic considerations [23]. The second views it as synonymous with CSR [24,25], including organisational practices for sustainability. The third views it as synonymous with the viability of the business or its operations in the long term [26], using organisational and management theories such as sustainable competitive advantage. Finally, the fourth construct understands the integration of sustainability into activities performed in the organisation as the only desirable state for achieving sustainable organisations [3].

Lankoski [3] defends integrated sustainability as the only possible alternative because it assumes that the organisation has performed an integral transformation process at all organisational levels.

- From a strategic perspective, integrated sustainability incorporates the responsibility of organisations towards the market. Organisations achieve economic growth by increasing 
competitiveness and environmental protection in two aspects (social and environmental), always with a long-term vision [27]. It must involve the entire organisation in achieving the objectives included in the three dimensions of sustainability (social, economic, and environmental), which entails a change in the understanding of the relationships with nature and people [8]. Hediger's idea [28] is also noteworthy: sustainability should maximise corporate value without depreciating with the passage of time $[9,27,29]$. This approach is mainly developed through the concept of Corporate Sustainability (CS) [30,31] or CSR [32].

- From an operational approach, it must be accompanied by sustainable management that is responsible for including the environmental and social factors of organisational activities. It must consider economic performance [33], and its objective must be to achieve an individualised result for each dimension of sustainability [3].

The integration of sustainability in organisations is analysed based on different approaches, perspectives, and interests (depending on the objectives that have been established and the definition of sustainability that has been adopted) [3]. A large number of tools, indicators, and models have been designed and identified to assess an organisation's sustainable performance or the integration of sustainability in an organisation, based on different approaches and areas of knowledge. These approaches can be classified based on their objectives, performance [34,35], strategy [36,37], or management $[9,17,32,38-41]$. They can also be classified depending on the tools proposed for quantification [42-48], communication [49-52], or integration [12,13] (Table 1). 
Table 1. Models of sustainability integration in organisations.

\begin{tabular}{|c|c|c|c|}
\hline Integration Approach & Authors & Scope/Basis & Integration Proposal \\
\hline \multirow[t]{2}{*}{ Sustainable performance } & Rajak and Vinodh [34] & Approach to assessing sustainability from a social perspective & $\begin{array}{l}\text { A social sustainability integration method divided into six steps: } \\
\text { literature review, conceptual model development, assessment of } \\
\text { social sustainability, approximation of linguistic terms by fuzzy } \\
\text { numbers, determination of the Fuzzy Social Sustainability Index } \\
\text { (FSSI), and identification and analysis of the Fuzzy Performance } \\
\text { Importance Index (FPII) }\end{array}$ \\
\hline & Nunes et al. [35] & $\begin{array}{l}\text { Systematic approach analyses the limits of the natural } \\
\text { environment using a toy model to model the sustainability } \\
\text { of systems }\end{array}$ & $\begin{array}{l}\text { The integration of sustainability by modelling the evolution of } \\
\text { systems under some restrictions; proposes the Sustainability } \\
\text { Management Model in Sweden }\end{array}$ \\
\hline \multirow[b]{2}{*}{ Sustainable strategy } & Kurucz et al. [36] & $\begin{array}{l}\text { Integrates the Framework for Strategic Sustainable Development } \\
\text { (FSSD) and the Planet Boundary Approach (PBA) }\end{array}$ & $\begin{array}{l}\text { The FSSD is structured into five levels: systems, success, strategic } \\
\text { guidelines, actions, and tools }\end{array}$ \\
\hline & Kuo et al. [37] & $\begin{array}{l}\text { Hybrid-modified Multiple Attribute Decision-Making model } \\
\text { combined with the Decision-Making Trial and Evaluation } \\
\text { Laboratory (DEMATEL) technique; considers sustainable } \\
\text { competitive advantage an aspiration level; } \\
\text { environmental approach }\end{array}$ & $\begin{array}{l}\text { Constructs the Influential Network Relation Map (INRM); } \\
\text { integrates sustainability and competitive advantage concepts to } \\
\text { formulate the most effective allocation strategies for } \\
\text { natural resources }\end{array}$ \\
\hline \multirow{6}{*}{ Management } & Shrivastava and Hart [9] & $\begin{array}{l}\text { Analysis of organisational design elements; sustainable } \\
\text { organisation design }\end{array}$ & Integrated environmental management \\
\hline & Leppelt et al. [38] & $\begin{array}{l}\text { Integrates Sustainable Supplier Relationship Management (SSRM) } \\
\text { in Sustainable Performance Management (SPM) [41]; focuses on } \\
\text { the chemical industry }\end{array}$ & Sustainability management beyond corporate limits \\
\hline & Marcelino-Sábada et al. [39] & $\begin{array}{l}\text { Identifies the lack of integration of sustainability in } \\
\text { project management }\end{array}$ & A new concept of sustainable project management \\
\hline & Mustapha et al. [40] & Integrates ISO standards, the Deming Cycle, or the PDCA Cycle & A green sustainable management system \\
\hline & Schaclok et al. [17] & $\begin{array}{l}\text { Incorporates continuous improvement criteria; drivers of change: } \\
\text { accounting, leadership, and the organisation }\end{array}$ & $\begin{array}{l}\text { The creation of a sustainability model through the systematic } \\
\text { approach of continuous quality improvement }\end{array}$ \\
\hline & Panagiotakopoulos et al. [32] & Incorporates ISO 26000 criteria in FSSD & The Viable System Model (VSM) \\
\hline \multirow{6}{*}{ Quantification } & Hörisch et al. [42] & Environmental approach & $\begin{array}{l}\text { Analysis of the effectiveness of management tools for } \\
\text { sustainability in large companies }\end{array}$ \\
\hline & Angelakoglou and Gaidajis [43] & Focuses on assessing environmental sustainability & A review of quantification tools \\
\hline & Phillips [44] & Rapid Impact Assessment Matrix [48] & The Geocybernetic Assessment Matrix (GAM) \\
\hline & Rahdari and Rostamy [45] & Quantification of indicators in general & Designing sustainability indicators \\
\hline & Kylili et al. [46] & $\begin{array}{l}\text { Quantification of indicators linked to construction } \\
\text { project management }\end{array}$ & Designing Performance Indicators (KPIs) \\
\hline & García et al. [47] & $\begin{array}{l}\text { Based on Hörisch et al. [42]; adaptation of the Integrated } \\
\text { Environmental Evaluation of Water Resources Development (IEE) } \\
\text { model; measures the Triple Bottom Line }\end{array}$ & $\begin{array}{l}\text { The Integrated Environmental Evaluation-Sustainability Business } \\
\text { (IEE-SB) model }\end{array}$ \\
\hline
\end{tabular}


Table 1. Cont.

\begin{tabular}{|c|c|c|c|}
\hline Integration Approach & Authors & Scope/Basis & Integration Proposal \\
\hline \multirow{4}{*}{ Communication } & Lozano and Huisingh [49] & Analysis of Sustainability Reporting (SR) & $\begin{array}{l}\text { Highlights the influence of sustainability reports as a mechanism } \\
\text { for integrating sustainability in organisations }\end{array}$ \\
\hline & Fonseca et al. [50] & $\begin{array}{l}\text { Based on Bellagio STAMP and how it covers the gaps of Global } \\
\text { Reporting Initiative (GRI) reports; focuses on the mining sector }\end{array}$ & $\begin{array}{l}\text { A conceptual proposal for sustainability evaluation } \\
\text { and communication }\end{array}$ \\
\hline & Hsu et al. [51] & $\begin{array}{l}\text { Analysis of the importance of materiality for engaging } \\
\text { stakeholders through sustainability reports; materiality analysis } \\
\text { method: Failure Modes and Effects Analysis (FMEA); Risk } \\
\text { Priority Numbers (RPNs); Analytic Network Process (ANP) }\end{array}$ & A proposal for a model to analyse the materiality of sustainability \\
\hline & Siew [52] & & A review of communication tools \\
\hline \multirow{2}{*}{ Integration } & Maas et al. [12] & $\begin{array}{l}\text { Analysis of three factors of sustainability: quantification, } \\
\text { management, and communication; perspectives of analysis: } \\
\text { inside-out/outside-in }\end{array}$ & A sustainability integration model in organisations \\
\hline & Morioka and de Carvalho [13] & $\begin{array}{l}\text { Four-factor analysis: processes and practices, capabilities, } \\
\text { offerings, contribution to the development of competitive } \\
\text { advantages; based on principles of CS and environmental factors }\end{array}$ & A sustainable performance integration model in organisations \\
\hline
\end{tabular}




\subsection{Sustainability Integration Models in Organisations}

This paper focuses on the analysis of two sustainability integration models (those proposed by Maas et al. [12] and Morioka and de Carvalho [13]), due to their strengths and because both are framed within sustainable management accounting models [12]. Both models feature the integration of different components and tools that seek to transform sustainable organisations.

Maas et al. [12] design a sustainability integration model that is based on three factors: measurement, management (accounting and control), and communication. These elements are analysed from two perspectives:

(1) The performance improvement perspective (inside-out). Sustainability is achieved with the improvement of sustainable performance and through the development of strategies based on quantification. A management accounting system that enables the appropriate selection of sustainability indicators is necessary. These indicators will facilitate system management in line with the objectives proposed in the strategy. This perspective simplifies the flow of information in the communication processes.

(2) The transparency perspective (outside-in). Pressure from stakeholders exerts a substantial impact on the behaviour of organisations, which influences organisational performance. Therefore, the development of high-quality sustainability reports is necessary, implying close and fluid communication with stakeholders.

Maas et al. [12] develop these perspectives and link them to measurement, sustainable management accounting, sustainable management control, and sustainability communication. These relationships are established through the following linkages:

- Sustainable measurement. This linkage allows useful information for sustainability reports to be obtained [53]. It is used in the decision-making process [54].

- Sustainable management accounting. This linkage refers to the processes of collection, analysis, and the communication of sustainability $[55,56]$. The results obtained are for internal use and help to improve organisational performance.

- Sustainable control management. This linkage includes designing and using controls (both formal and informal) that guarantee and ensure alignment between the behaviour and decisions of an organisation's employees and the objectives and strategies of the organisation [57].

- Sustainable communication. Sustainable organisations seek effective information and communication [58,59], which increases interaction with stakeholders [60,61], legitimacy, and reputation [62,63], as well as employee motivation [64].

The model for integrating sustainability performance into organisations (by Morioka and de Carvalho) [13] is based on the influence of CS factors on the development of "sustainable elements". There are four CS factors: (1) stakeholder engagement [65,66]; (2) sustainability management and the sustainable performance of the organisation; (3) internal contextual factors, derived from strategic sustainability integration plans [67]; and (4) internal contextual factors, such as legislation and the natural environment [68]. The four sustainable elements are as follows:

(1) Capabilities are defined as the adaptive capacity of the organisation to implement necessary changes in its culture and structure in pursuit of sustainability [69].

(2) Processes and practices contribute to sustainability when they are aligned with sustainability strategy principles. Therefore, they must be associated with a sustainable value chain (SVC) [33], include good practices in collaboration with suppliers [70], and consider the information from the operations performed in the organisation [71] (such as green purchasing [72], eco-design [73], or the use of quality management and environmental management systems [74,75]).

(3) Offerings refer to innovation [66] and reduced environmental burden [76] in the sale of products and services. 
(4) Elements related to the development of competitive advantages and their contribution to sustainable development are defined as the effort that organisations make to create sustainable value and promote the wellbeing of society and environmental conservation [77].

These models present certain disadvantages and shortcomings. Maas et al. [12] identify deficiencies or an absence of linkages that prevent the complete incorporation of sustainability at all levels of an organisation, from two perspectives:

(1) The performance improvement perspective (inside-out), in which there is a lack of connection between sustainable strategy and the assessment of sustainability.

(2) The transparency perspective (outside-in), in which there is a lack of connection between sustainable communication and sustainability control management and, within this, sustainable accounting management.

(3) Both perspectives: Maas et al. [12] identify a disconnection between sustainability control management and sustainability assessment, and between sustainable management accounting and sustainable communication.

The model defined by Morioka and de Carvalho [13] is a conceptual proposal based on a restrictive sample. It does not state the rules for identifying the sustainability elements or how they can be integrated through the activities developed by organisations. This model claims to integrate sustainability into organisations but does not provide guidelines on how to do so.

\subsection{Sustainable Value Chain}

The SVC [1] is based on Porter's [78] concept of the value chain and incorporates the criteria of sustainability. Porter and Kramer [1] observe a substantial expansion of CSR inclusion in organisations and suggest that this is due to pressures generated by the risks of global warming, the multiplication of government regulations and the publication of lists of companies showing their ethical, social, and environmental protection measures. Thus, these authors analyse the relationship between companies and society to define a SVC. To this end, they explore the connections between society and organisations from two perspectives [1]:

(1) The inside-out perspective: Each activity in the value chain is considered to have an impact on the community in which it operates, and to have positive and/or negative social consequences.

(2) The outside-in perspective: Organisations develop their activities in a competitive environment. Therefore, understanding the dimensions of the external environment will enable the organisation to develop actions that improve productivity and help it to execute its strategy.

\section{Activity-Based Sustainability Model (ABS Model)}

The model by Morioka and de Carvalho [13] (which is similar to the model of Maas et al. [12]) proposes only general guidelines for sustainability integration and does not define how to achieve this integration. Previous models integrate sustainability in organisations, although none of the models is presented as definitive, due to the complexity involved in implementing these models in organisations [3].

Framed within models of sustainable management accounting, the main function of the ABS model is to provide quantitative and qualitative information on the social, environmental, and economic impacts that occur in the internal transformation process, thereby generating useful information for decision making and integral sustainability management at all levels of the organisation. It aims to be a solution for the creation of sustainable organisations from an inside-out perspective. Thus, it is an internal analysis model that enables organisations to be sustainable. It identifies the improvement actions of impacts on the external environment by considering the objectives of sustainable development. Furthermore, it offers greater transparency through the communication of the actions of organisations. 


\subsection{ABS Model Foundations}

Morioka and de Carvalho [13] advocate for the use of the SVC in an effort to provide information on how organisations can perform their activities from an internal perspective of sustainability [32]. The analysis of the SVC is a theoretical business model developed by Porter and Kramer [1] that determines how organisations generate value and develop competitive advantages through CSR criteria [1]. The use of the SVC facilitates the creation of the sustainable competitive advantages proposed in Morioka and de Carvalho's model [13], because it provides information about how activities can be performed from an internal perspective of sustainability. If we combine both constructs, it follows that the activities must be the centre of analysis to integrate sustainability in organisations.

The manner in which the ABS model relates resources, activities, processes, and outputs is similar to that offered by accounting management and its Activity-Based Costing (ABC) model (according to which activities consume resources), and it is through these activities that economic costs are assigned by accumulation. However, the analysed element in the ABS model is not a cost but an impact (social, environmental, or economic) that accumulates through activities. The impact of these activities is what must be understood.

In contrast, the concept of SVC by Porter and Kramer [1] is used to define activities from the inside-out perspective, and uses the SVC as a tool that allows organisations to be studied and understood based on the activities they perform. These activities need to be strategically relevant to facilitate the study and understanding of their sustainable behaviour [79]. This concept is considered a basic tool in the strategic management of the organisation for the development of sustainable competitive advantages [80].

The reasons for this choice are as follows [81]:

(1) It is a model applicable to any type of organisation, regardless of structure.

(2) It is an approximate representation of the relationship between the productive system and the corporate level.

(3) It is an invaluable tool for conducting an internal analysis of organisations, as it represents all the relevant activities that a company must perform to generate sustainable value through the sale of a product, service, and/or idea.

\subsection{The ABS Model Process}

The essence of the ABS model involves assigning impacts to objects that are analysed in terms of sustainability (objects of impact). These objects may include products, services, clients or groups of clients, or markets. The activities performed under the auspices of the organisation are considered to be those that generate impact. The objects of impact are those that consume activities. Therefore, understanding the activities that form part of an organisation's value chain allows the impact caused by the objects of impact to be quantified from Porter and Kramer's inside-out perspective [1].

The ABS model consists of an initial phase in which the sustainability aspects that the organisation will analyse are selected to determine sustainability indicators and their impact. The model then follows steps that are similar to those in the ABC model. In a first stage, the resource consumption (in terms of impact) generated by each of the activities in the SVC is established. As a result, the impact of each activity is obtained. The second stage consists of assigning the impacts of the activities to the object of impact (that is, to the object whose impact is to be understood) (Figure 1).

The model allows managers to determine why impacts related to activities occur. The result is a sustainability indicator that meets the requirements and characteristics of Rahdari and Rostamy [45], and therefore facilitates the assessment of organisational performance. This knowledge allows management to be sustainable by eliminating activities that are unnecessary and that are, therefore, suppressing their impacts by improving activities that require higher efficiency (or enhancing those that generate higher sustainable value in the organisation). Ultimately, this model provides necessary 
information for sustainable decision making and ensures that these decisions are oriented towards the implementation of sustainability strategies.

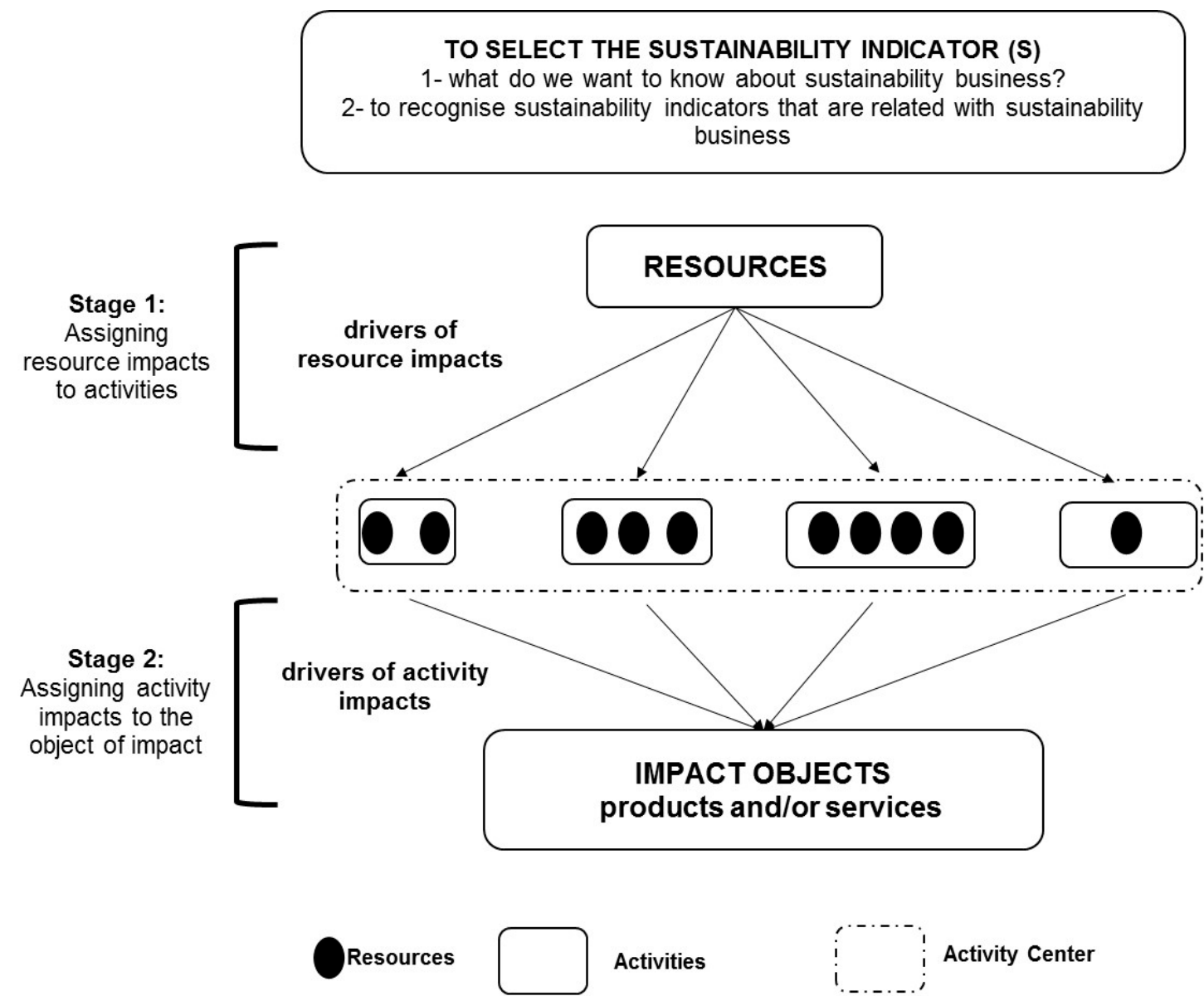

Figure 1. ABS model. Application procedure.

\subsection{Scope of the ABS Model}

The analysis of the SVC through management accounting procedures makes it possible to establish a connection between corporate activities and operational activities for any type of organisation, and to establish a connection among resources, activities, and processes. The analysis must be aligned with the objectives defined in organisation sustainability strategies. Finally, the analysis must provide useful internal and external information for making decisions concerning the organisation's sustainability.

From an internal perspective (inside-out), the ABS model facilitates the link between sustainable management accounting and sustainable communication, and between sustainable management control and sustainability assessment (connections that Mass et al. [12] lacked), in order to establish sustainability integration:

- Sustainability assessment allows the measurement of sustainability through useful, relevant, understandable, and comparable indicators.

- Sustainable management control facilitates the analysis of deviations between actual and planned data.

- Sustainable management accounting serves to support sustainability standards and management, fulfilling the functions of capturing, measuring, and assessing production activities. It influences planning, resource rationalisation, and controlling activities (as well as the organisation's decision-making process). 
- Sustainable communication for the learning process and organisational improvement.

\section{Implications of the ABS Model for Sustainability Integration Models}

The ABS model is presented as a solution to the constraints defined in the sustainability integration models designed by Maas et al. [12] and Morioka and de Carvalho [13]. The ABS model is broadly applicable. Primarily, it helps organisations incorporate sustainability. It solves the restrictions found in the model of Maas et al. [12] and transforms the conceptual model defined by Morioka and de Carvalho [13] into an operational model, because it facilitates the identification of activities and links the sustainability elements identified in the model of Morioka and de Carvalho [13].

\subsection{The ABS Model and the Sustainability Integration Model in Organisations}

The ABS model is offered as a possible solution to the lack of connections identified in the model of Maas et al. [12]. Because it is an internal analysis model of organisations that presents a relationship among resources, activities, and products/services with the final result of a sustainability indicator, it can be incorporated into the model of Maas et al. [12]. Thus, we establish connections between sustainable control management and sustainability assessment, and between sustainable management accounting and sustainability communication (Figure 2):

(1) The link between management control systems and sustainability assessment methods: The most immediate result of the ABS model is sustainability indicators that, due to their characteristics and those of the ABS model, can (a) describe the organisation's situation with regard to sustainable topics; and (b) establish a control mechanism with regard to the actions implemented to reduce their impacts (because the ABS model establishes a relationship between activity and impact, that allows the implementation of specific reduction and/or elimination actions). These can be verified on the basis of the fulfilment of the established objectives (otherwise, it enables error identification to correct actions that generate deviations from the established objectives).

(2) The link between sustainable management accounting and sustainable communication: One result of the ABS model is a sustainability indicator. It can provide information about the organisation's actions, fulfilling the requirements of the standards for the preparation of sustainability reports. For example, if the organisation wants to know its contribution to climate change, it can measure its carbon footprint with the ABS model and can include this measurement among the climate change indicators of the GRI report.

These issues are based on the assumption that the ABS model is analogous to the ABC model; therefore, its characteristics and application in sustainable management accounting are assumed. This would allow the following linkages (Figure 2):

(1) The link between measuring sustainability and sustainable management control. One of the objectives of cost accounting is to plan and control operations, activities, and resources. Thus, an analysis of the organisation's internal efficiency is developed. The ABS model provides information on the impact generated by these activities. Therefore, one of the model's results is an analysis of the organisational structure regarding the assessment of environmental sustainability.

(2) The link between sustainable management accounting and sustainable communication. Communication aims to provide information to stakeholders on the organisation's activities with respect to sustainability. Thus, the ABS model provides sustainability indicators that comply with this use for communication. 


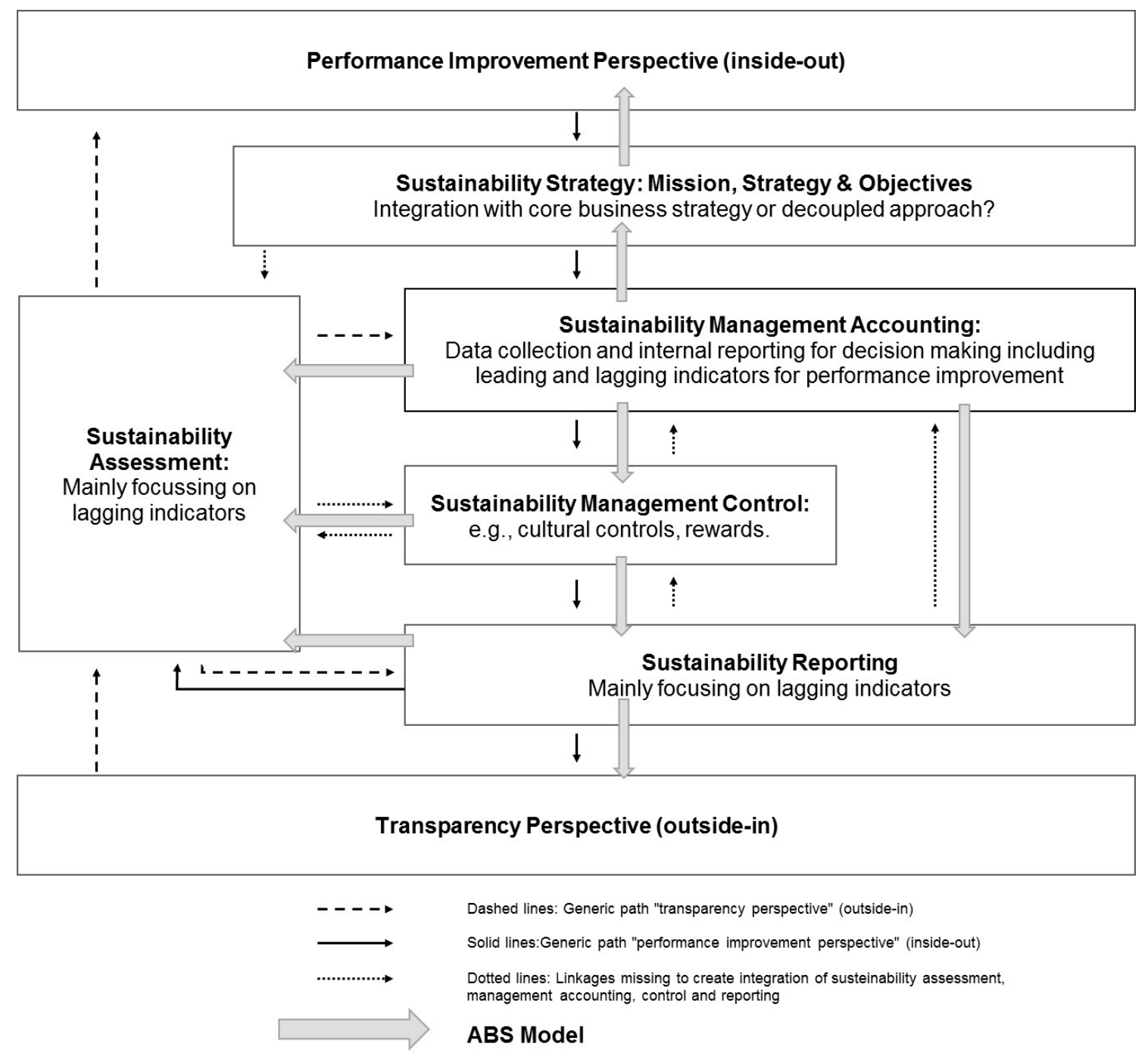

Figure 2. The ABS model in the sustainability integration model of organisations. Source: Prepared by the authors based on Maas et al. [12].

\subsection{The ABS Model and the Sustainability Integration Model Based on Organisational Performance}

Focusing on the model of Morioka and de Carvalho [13] (and the improvements that the proposed ABS model can introduce), the analysis is framed within the sustainable elements of the organisation (Figure 3). The ABS model establishes a relationship among resources, activities, processes, and products/services. Therefore, the sustainable element called "processes and practices" by Morika and Carvalho [13] must be determined and defined. This makes it possible to know the organisation internally and identify the processes that are less sustainable. Thus, decision makers can develop a plan of action that facilitates the transformation of the organisation into a sustainable one. Moreover, once this element is conceptualised, it establishes relationships with the rest of the sustainable elements defined in Morioka and Carvalho's model [13]:

- Capabilities: Knowledge of the resources consumed by the activities and the transformation process of the organisation allows for (1) determination of what type of technology to use and how to use it to be more sustainable; (2) knowledge of the resources available and how they should be used for greater efficiency; (3) knowledge of what type of resources are needed to achieve sustainability; and (4) knowledge of the competencies that must be acquired to create a sustainable organisation. 
- Offerings: If a sustainable transformation process is achieved, the product/service will be sustainable. The result of the ABS model is the impact, good or bad, of the product or service generated in the organisation.

- Contributions to sustainable development as a competitive advantage: The ABS model implies the development of sustainable competitive advantages because it is based on the concept of SVC (defined by Porter and Kramer) [1]. In addition, the ABS model contributes to sustainable development because its purpose is the integration of sustainability into the organisation, which (according to Morioka and Carvalho [13]) is how organisations can contribute to sustainable development.

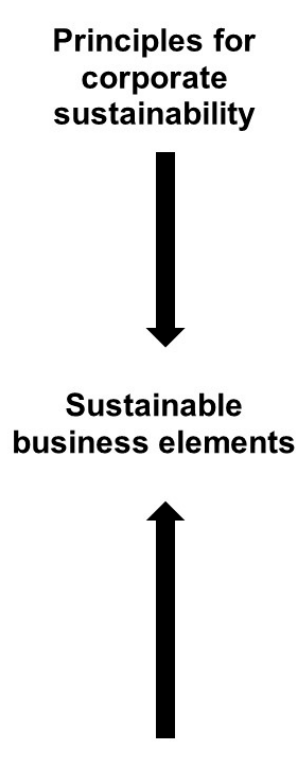

Context factor
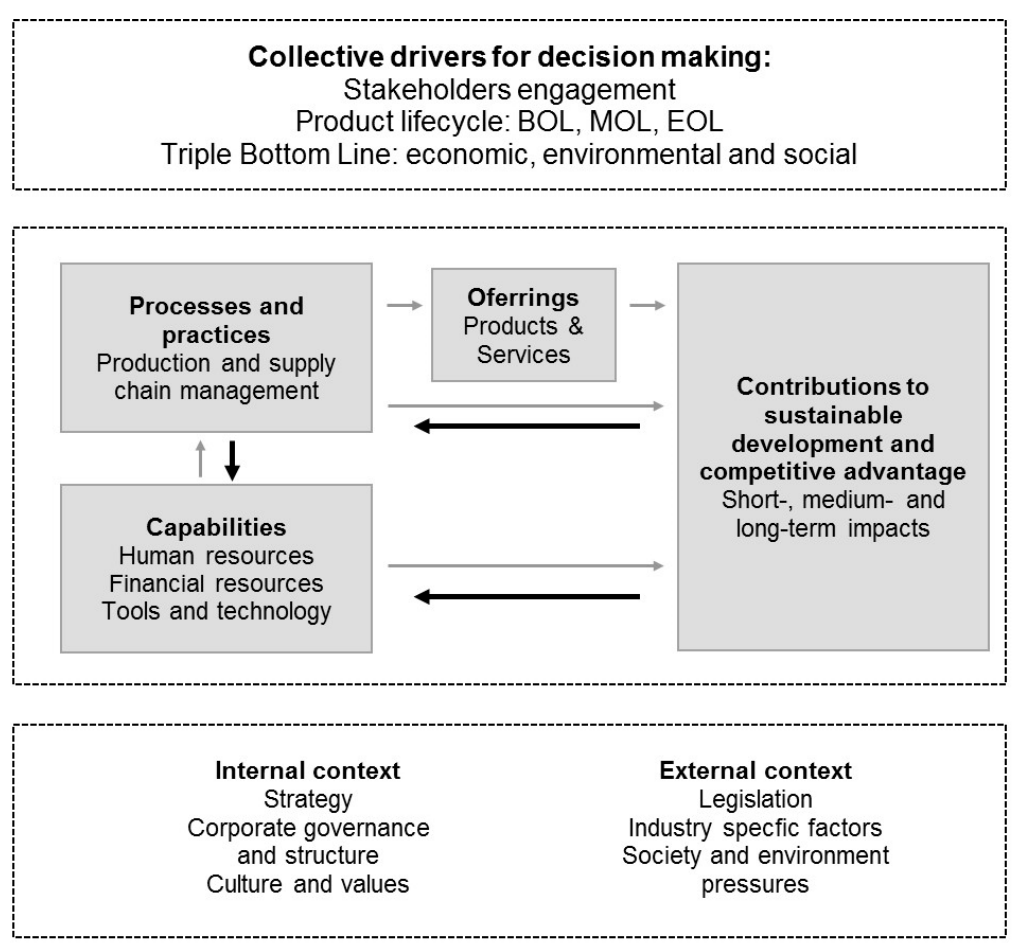

\section{ABS Model}

Relationships between elements of the organisation for seeking sustainability

Figure 3. The ABS model and the integration model of organisational performance. Source: Prepared by the authors, based on Morioka and de Carvalho [13].

In addition, the ABS model establishes a relationship among sustainable elements, the CS principles, and the context factor [13], as follows:

(1) The ABS model allows the sustainable management of the organisation's value chain and supply chain, based on the impacts (good and/or bad) that are generated by the activities and processes involved. Thus, the ABS model can be applied to any organisation that wants to introduce sustainability criteria into its internal processes.

(2) The output of the ABS model is a sustainability indicator that reflects the efficiency of the structure of the organisation, and thus facilitates the assessment of the organisation's sustainable performance. Therefore, it provides a useful tool for assessing the sustainability performance of organisations, which is lacking in the model of Morioka and Carvallo [13].

(3) The ABS model facilitates the quantification of the Triple Bottom Line because it is able to analyse any indicator related to the sustainability strategy of an organisation. 
(4) The ABS model follows the CSR criteria and takes into account the stakeholders. Therefore, it must comply with current legislation (both in general and with regard to the economic sector to which it belongs), and act respectfully and in view of the improvement of the environment (both environmental and social).

\section{Conclusions}

Sustainability is a relevant factor for the creation of value in organisations. It must be implemented in these organisations to establish the necessary connections among management accounting, management systems, and communication in the integrated implementation of sustainability in organisations. This is evidenced by the large number of existing models, methods, and tools, all of which aim to make organisations sustainable. This situation creates uncertainty for those who want to implement a transformation towards sustainability and promote sustainable development.

In this context, the ABS model (based on both the ABC model and the SVC) facilitates integrated sustainable management in organisations regardless of the results of the analysis of the impacts, products, services, clients, and markets, in that it proposes a technique to incorporate sustainability in organisations according to the paradigm presented by Maas et al. [12] and Morioka and de Carvalho [13]. The ABS model shows its strength from an internal activity-based perspective. Thus, the resources that these activities consume and the processes in which they are involved can be understood. This knowledge provides sufficient information to know how sustainable an organisation is and to establish an action plan that enables the integration of sustainability into the organisation. This integration can be achieved through the development of sustainable skills and the introduction of new and more efficient technologies. As a result, organisational culture and the development of competitive advantages and sustainable strategies are also internalised.

The ABS model offers a tangible result that is an indicator of sustainability. This facilitates the assessment of the organisation's sustainable performance, which is important for decision making and knowledge of whether the objectives established in the sustainability strategies are achieved. Moreover, this indicator helps the communication processes of the organisation, as it provides objective information on the progress of the organisation's sustainability. This can be used for both external and internal communication processes, thus facilitating the incorporation of stakeholders (another important element in the incorporation of sustainability in the organisation).

The ABS model is presented as an alternative to link the levels of sustainable management accounting and sustainable communication (as well as those of sustainable management control and sustainability assessment), which Maas et al. [12] define in their model but fail to describe how to perform. In addition, it is a means of connecting the sustainable elements of Morioka and de Carvalho [13] because it allows the bilateral identification of the linkages that exist between skills, processes, and practices. Similarly, it connects these links with the contribution to sustainable development and the development of competitive advantages. Thus, the ABS model can be a necessary element to integrate sustainability in organisations at all levels.

Thus, a connection among processes and practices, as well as with the development of competitive advantages, is established. The ABS model establishes a relationship among resources, activities, processes, and products/services. It can be used to identify necessary actions in the development of a CS strategy so that these are in line with the environmental factors to which the organisation is committed. This allows managers to link organisational processes with stakeholders' needs. Similarly, the model facilitates the development of competencies and skills for sustainability. In addition, given that the tool to analyse activities is the value chain of Porter and Kramer [1], it enables the identification of sources of competitive advantage generation.

The main limitation of the model lies in the need to identify and describe processes, locate every activity that constitutes the value chain, and quantify the impacts of these activities. This may be difficult if the organisation has not previously implemented an activity-based management accounting system. 
Future lines of research based on this proposal could focus on adapting this model to each of the facets of sustainability. Thus, in the case of environmental sustainability models, "footprint"-type indicators would be used. Because this is a model, it requires field validation.

Author Contributions: Ana Rodriguez-Olalla and Carmen Avilés-Palacios conceived and developed the model. Ana Rodriguez-Olalla and Carmen Avilés-Palacios analysed the results and wrote the manuscript. All authors have read and approved the final manuscript.

Conflicts of Interest: The authors declare no conflict of interest.

\section{References}

1. Porter, M.E.; Kramer, M.R. Strategy \& Society: The link between competitive advantage and corporate social responsibility. Harv. Bus. Rev. 2006, 84, 78-92. [PubMed]

2. Figge, F.; Hahn, T. Sustainable value added-Measuring corporate contributions to sustainability beyond eco-efficiency. Ecol. Econ. 2004, 48, 173-187. [CrossRef]

3. Lankoski, L. Alternative conceptions of sustainability in a business context. J. Clean. Prod. 2016, 139, 847-857. [CrossRef]

4. Asif, M.; Searcy, C.; Zutshi, A.; Fisscher, O.A.M. An integrated management systems approach to corporate social responsibility. J. Clean. Prod. 2013, 56, 7-17. [CrossRef]

5. Waage, S.A.; Geiser, K.; Irwin, F.; Weissman, A.B.; Bertolucci, M.D.; Fisk, P.; Basile, G.; Cowan, S.; Cauley, H.; McPherson, A. Fitting together the building blocks for sustainability: A revised model for integrating ecological, social and financial factor into business decision-making. J. Clean. Prod. 2005, 13, 1145-1164. [CrossRef]

6. Hart, S.L.; Christensen, C.M. The Great Leap. Driving Innovation form the "Base of the Pyramid". MIT Sloan Manag. Rev. 2002, 44, 51-57.

7. Robinson, J. Squaring the circle? Some thoughts on the idea of sustainable development. Ecol. Econ. 2004, 48, 369-384. [CrossRef]

8. Hopwood, B.; Mellor, M.; O’Brien, G. Sustainable development: Mapping different approaches. Sustain. Dev. 2005, 13, 38-52. [CrossRef]

9. Shrivastava, P.; Hart, S.L. Creating Sustainable Corporations. Bus. Strategy Environ. 1995, 4, $154-165$. [CrossRef]

10. Carter, C.R.; Rogers, D.S. A framework of sustainability supply chain management: Moving toward new theory. Int. J. Phys. Distrib. Logist. Manag. 2008, 35, 177-194. [CrossRef]

11. Maas, K.; Schaltegger, S.; Crutzen, N. Advancing the integration of corporate sustainability measurement, management and reporting. J. Clean. Prod. 2016, 133, 859-862. [CrossRef]

12. Maas, K.; Schaltegger, S.; Crutzen, N. Integrating corporate sustainability assessment, management accounting, control and reporting. J. Clean. Prod. 2016, 136, 237-248. [CrossRef]

13. Morioka, S.N.; de Carvalho, M.M. A systematic literature review towards a conceptual framework for integrating sustainability performance into business. J. Clean. Prod. 2016, 136, 134-146. [CrossRef]

14. Mokate, K.M. Eficacia, Eficiencia, Equidad y Sostenibilidad: ¿Qué Queremos Decir? Banco Interamericano de Desarrollo; Departamento de Integración y Programa Regionales: Washington, DC, USA, 2001. (In Spanish)

15. Marshall, J.D.; Toffel, M.W. Framing the elusive concept of sustainability: A sustainability hierarchy. Environ. Sci. Technol. 2005, 39, 673-682. [CrossRef] [PubMed]

16. Bolis, I.; Morioka, S.N.; Sznelwar, L.I. When sustainable development risks losing its meaning. Delimiting the concept with a comprehensive literature review and a conceptual model. J. Clean. Prod. 2014, 83, 7-20. [CrossRef]

17. Schalock, R.L.; Verdugo, M.; Lee, T. A systematic approach to an organisation's sustainability. Eval. Progr. Plan. 2016, 56, 56-63. [CrossRef] [PubMed]

18. Wiedmann, T.O.; Lenzen, M.; Barrett, J.R. Companies on the scale: Ecological foundations for corporate sustainability. J. Manag. Stud. 2009, 50, 307-336. [CrossRef]

19. Ketola, T. Five laps to corporate sustainability through a corporate responsibility portfolio matrix. Corp. Soc. Responsib. Environ. Manag. 2010, 17, 320-336. [CrossRef] 
20. Schaltegger, S.; Wagner, M. Sustainable entrepreneurship and sustainability innovation: Categories and interactions. Bus. Strategy Environ. 2011, 20, 222-237. [CrossRef]

21. Schrettle, S.; Hinz, A.; Scherrer-Rathje, M.; Friedli, T. Turning sustainability into action: Explaining firm's sustainability efforts and their impact on firm performance. Int. J. Prod. Econ. 2014, 147, 73-84. [CrossRef]

22. Figge, F.; Hahn, T.; Schaltegger, S.; Wagner, M. The sustainability balanced scorecard-linking sustainability management to business strategy. Bus. Strategy Environ. 2002, 11, 269-284. [CrossRef]

23. Lozano, R. Developing collaborative and sustainable organisations. J. Clean. Prod. 2008, 16, 499-509. [CrossRef]

24. Montiel, I. Corporate social responsibility and corporate sustainability: Separate pasta, common future. Organ. Environ. 2008, 21, 245-269. [CrossRef]

25. Okoye, A. Theorising corporate social responsibility as an essentially contested concept: Is a definition necessary? J. Bus. Ethics 2009, 89, 613-627. [CrossRef]

26. Lozano, R. A holistic perspective on corporate sustainability drivers. Corp. Soc. Responsib. Environ. Manag. 2015, 22, 32-44. [CrossRef]

27. Elkintong, J. Partnerships from cannibals with forks: The triple bottom line of 21st Century Business. Environ. Qual. Manag. 1998, 8, 37-51. [CrossRef]

28. Hediger, W. Welfare and capital-theoretic foundation of corporate social responsibility and corporate sustainability. J. Socio-Econ. 2010, 39, 518-526. [CrossRef]

29. Toro, D. El enfoque estratégico de la responsabilidad social corporativa: Revisión de la literatura académica. Intang. Cap. 2006, 2, 338-358. (In Spanish).

30. Dyllick, T.; Hockerts, K. Beyond the business case for corporate sustainability. Bus. Strategy Environ. 2002, 11, 130-141. [CrossRef]

31. Lozano, R. Towards better embedding sustainability into companies's systems: An analysis of voluntary corporate initiative. J. Clean. Prod. 2012, 25, 14-16. [CrossRef]

32. Panagiotakopoulos, P.D.; Espinosa, A.; Walker, J. Sustainability management: Insights from the viable system model. J. Clean. Prod. 2016, 113, 792-806. [CrossRef]

33. Seuring, S.; Müller, M. From literature review to a conceptual framework for sustainable supply chain management. J. Clean. Prod. 2008, 16, 1699-1710. [CrossRef]

34. Rajak, S.; Vinodh, S. Application of fuzzy logic for social sustainability performance evaluation: A case study of an Indian automotive component manufacturing organisation. J. Clean. Prod. 2015, 108, 1184-1192. [CrossRef]

35. Nunes, B.; Alamino, R.C.; Shaw, D.; Bennett, D. Modelling sustainability performance to achieve absolute reductions in socio-ecological systems. J. Clean. Prod. 2016, 132, 32-44. [CrossRef]

36. Kurucz, E.C.; Colbert, B.A.; Lüdeke-Freund, F.; Upward, A.; Willard, B. Relational leadership for strategic sustainability: Practices and capabilities to advance the design and assessment of sustainable business models. J. Clean. Prod. 2016, 1-16. [CrossRef]

37. Lu, I.-Y.; Lin, T.-S.; Tzeng, G.-H.; Huang, S.-L. Multicriteria Decision Analysis to develop effective sustainable development strategies for enhancing competitive advantage: Case of the TFT-LCD Industry in Taiwan. Sustainability 2016, 8, 646. [CrossRef]

38. Leppelt, T.; Foerstl, K.; Reuter, C.; Hartmann, E. Sustainability management beyond organisational boundaries-sustainable supplier relationship management in the chemical industry. J. Clean. Prod. 2013, 56, 94-102. [CrossRef]

39. Marcelino-Sábada, S.; Gónzalez-Jaen, L.F.; Pérez-Ezcurdia, A. Using Project management as a way to sustainability. From a comprehensive review to a framework definition. J. Clean. Prod. 2015, 99, 1-16. [CrossRef]

40. Mustapha, M.A.; Manan, Z.A.; Alwi, S.R.W. Sustainbale Green Management System (SGMS)—An integrated approach towards organisational sustainability. J. Clean. Prod. 2016. [CrossRef]

41. Svenson, G.; Wood, G.; Callaghan, M. A corporate Model of sustainable business practices: An ethical perspective. J. World Bus. 2010, 45, 335-345. [CrossRef]

42. Hörisch, J.; Ortas, E.; Schaltegger, S.; Álvarez, I. Environmental effects of sustainability mangement tools: An empirical analysis of large companies. Ecol. Econ. 2015, 120, 241-249. [CrossRef]

43. Angelakoglou, K.; Gaidajis, G. A review of methods contributing to the assessment of the environmental sustainability of industrial systems. J. Clean. Prod. 2015, 108, 725-747. [CrossRef] 
44. Phillips, J. The Geocybernetic Assessment Matrix (GAM)—A new assessment tool of evaluating the level and nature of sustainability or unsustainability. Environ. Impact Assess. Rev. 2016, 56, 88-101. [CrossRef]

45. Rahdari, A.H.; Rostamy, A.A.A. Designing a General Set of Sustainability Indicators at the Corporate Level. J. Clean. Prod. 2015. [CrossRef]

46. Kylili, A.; Fokaides, P.A.; Lopez-Jimenez, P.A. Key Performance Indicator (KPIs) approach in buildings renovation for the sustainability of the built environment: A review. Renew. Sustain. Energy Rev. 2016, 56, 906-915. [CrossRef]

47. Garcia, S.; Cintra, Y.; Torres, R.C.S.R.; Lima, F.G. Corporate sustainability management: A proposed multi-criteria model to support balanced decision-making. J. Clean. Prod. 2016. [CrossRef]

48. Pastakia, C.M.R.; Jensen, A. The rapid impact assessment matrix (RIAM) for EIA. Environ. Impact Assess. Rev. 1998, 18, 461-482. [CrossRef]

49. Lozano, R.; Huisingh, D. Inter-linking issues and dimensions in sustainability reporting. J. Clean. Prod. 2011, 19, 99-107. [CrossRef]

50. Fonseca, A.; McAllister, M.L.; Fitzpatrick, P. Sustainability reporting among mining corporations: A constructive critique of the GRI approach. J. Clean. Prod. 2014, 84, 70-83. [CrossRef]

51. Hsu, C.W.; Lee, W.H.; Chao, W.C. Materiality analysis in sustainability reporting: A case study at Lite-On Technology Corporation. J. Clean. Prod. 2013, 57, 142-151. [CrossRef]

52. Siew, R.Y.J. A review of corporate sustainability reporting tools (SRTs). J. Environ. Manag. 2015, 164, $180-195$. [CrossRef] [PubMed]

53. Pope, J.; Annandale, D.; Morrison-Saunders, A. Conceptualising sustainability assessment. Environ. Impact Assess. Rev. 2004, 24, 595-616. [CrossRef]

54. Azzone, G.; Brophy, M.; Noci, G.; Welford, R.; Young, W. A stakeholder's view of environmental reporting. Long Range Plan. 1997, 30, 699-709. [CrossRef]

55. Schaltegger, S.; Burritt, R. Contemporary Environmental Accounting: Issues, Concepts and Practice; Greenleaf: Sheffield, UK, 2000; ISBN 1-874719-35-7.

56. Schaltegger, S.; Burritt, R. Sustainability accounting for companies: Catchphrase or decision support for business leaders? J. World Bus. 2010, 45, 375-384. [CrossRef]

57. Malmi, T.; Brown, D.A. Management control systems as a package-opportunities, challenges and research directions. Manag. Account. Res. 2008, 19, 287-300. [CrossRef]

58. Christofi, A.; Chirstofi, P.; Sisaye, S. Corporate sustainability: Historical development and reporting practice. Manag. Res. Rev. 2012, 35, 157-172. [CrossRef]

59. Hahn, R.; Kühnen, M. Determinants of sustainability reporting: A review of results, trend, theory and opportunities in an expending field of research. J. Clean. Prod. 2013, 59, 5-21. [CrossRef]

60. Global Reposting Initiative (GRI). Sustainability Reporting Guidelines 2002. Available online: www. globalreporting.org (accessed on 20 January 2017).

61. Zadek, S.; Merme, M. Redefining Materiality: Practice and Public Policy for Effective Corporate Reporting; Institute of Social and Ethical Accountability: London, UK, 2003.

62. Kolk, A. Trends in sustainability reporting by the Fortune Global 2050. Bus. Strategy Environ. 2003, 12, 279-291. [CrossRef]

63. Lindgreen, A.; Swaen, V. Corporate Social Responsibility. Int. J. Manag. Rev. 2010, 12, 1-7. [CrossRef]

64. Weil, W.B.; Winter-Watson, B. The Internet and Sustainability Reporting: Improving Communication with stakeholders. In The Ecology of the New Economy: Sustainable Transformation of Global Information, Communications and Electronics Industries; Greenleaf Publishing in Association with GSE Research: Oxford, UK, 2002; pp. 85-95.

65. Dentchev, N. Corporate social performance: Business rationale, competitiveness threats and management challenges. Bus. Soc. 2007, 46, 104-116. [CrossRef]

66. Gadenne, D.; Mila, L.; Sand, J.; Winata, L.; Hooi, G. The influence of sustainability performance management practices on organisational sustainability performance. J. Account. Organ. Chang. 2012, 8, 201-235. [CrossRef]

67. Klassen, R.D.; McLaughlin, C.P. The impact of environmental management on firm performance. Manag. Sci. 1996, 42, 1199-1214. [CrossRef]

68. Kolk, A.; Mauser, A. The evolution of environmental management: From stage models to performance evaluation. Bus. Strategy Environ. 2002, 11, 14-31. [CrossRef] 
69. Pereira-Moliner, J.; Claver-Cortés, E.; Molina-Azorín, J.F.; Tarí, J.J. Quality management, environmental management and firm performance: Direct and mediating effects in the hotel industry. J. Clean. Prod. 2012, 37, 82-92. [CrossRef]

70. Grosvold, J.; Hoejmdes, S.U.; Roehrich, J.K. Squaring the circle: Management, measurement and performance of sustainability in supply chains. Supply Chain Manag. Int. J. 2014, 19, 292-305. [CrossRef]

71. Stefanelli, N.O.; Chiappetta Jabbour, C.J.; de Sousa Jabbour, A.B.L. Green supply chain management and environmental performance of firms in the bioenergy sector in Brazil: An exploratory survey. Energy Policy 2014, 75, 312-315. [CrossRef]

72. Chiappetta Jabbour, C.J.; de Sousa Jabbour, A.B.L.; Govindan, K.; Teixeira, A.A.; de Souza Freitas, W.R. Environmental management and operational performance in Automotive companies in Brazil: The role of human resource management and lean manufacturing. J. Clean. Prod. 2013, 47, 129-140. [CrossRef]

73. Chang, R.Y.K.; He, H.; Kai, H.; Wang, W.Y.C. Environmental orientation and corporate performance: The mediation mechanism of green supply chain management and moderating effect of competitive intensity. Ind. Mark. Manag. 2012, 41, 621-630. [CrossRef]

74. Yang, M.G.; Hong, P.; Modi, S.B. Impact of lean manufacturing and environmental management on business performance: An empirical study of manufacturing firms. Int. J. Prod. Econ. 2011, 129, 251-261. [CrossRef]

75. Benavides-Velasco, C.A.; Quintana-García, C.; Marchante-Lara, M. Management total quality management, corporate social responsibility and performance in the hotel industry. Int. J. Hosp. Manag. 2014, 41, 77-87. [CrossRef]

76. Huang, Y.C.; Wong, Y.J.; Yang, M.L. Proactive environmental management and performance by a controlling family. Manag. Res. Rev. 2014, 37, 210-214. [CrossRef]

77. Chinander, K.R. Aligning accountability and awareness for environmental performance in operations. Prod. Oper. Manag. 2001, 10, 276-291. [CrossRef]

78. Porter, M.E. Competitive Advantage: Creating and Sustaining Superior Performance; Free Press: New York, NY, USA, 1985.

79. Porter, M.E. Ventaja Competitiva. Creación y Sostenibilidad de un Rendimiento Superior; Ediciones Pirámide S.A.: Madrid, Spain, 2013. (In Spanish)

80. Hart, S.L. A Natural Resource Based View of the Firm. Acad. Manag. Rev. 1995, 20, 986-1014.

81. Menguzzato, M.; Renau, J.J. La Dirección Estratégica de la Empresa. Un Enfoque Innovador del Management; Editorial Ariel S.A.: Barcelona, Spain, 1991. (In Spanish) 